DORA NALETINA, Ph.D. ${ }^{1}$

(Corresponding author)

E-mail: dvuletic@net.efzg.hr

KRISTINA PETLJAK, Ph.D. ${ }^{1}$

E-mail:kpetljak@efzg.hr

TOMISLAV ROŽIĆ, Ph.D. ${ }^{2}$

E-mail: tomislav.rozic@fpz.hr

${ }^{1}$ Faculty of Economics and Business,

University of Zagreb

Trg J.F. Kennedy 6, 10000 Zagreb, Croatia

${ }^{2}$ Faculty of Transport and Traffic Sciences,

University of Zagreb

Vukelićeva 4, 10000 Zagreb, Croatia
Transport Technology

Preliminary Communication

Submitted: 1 Mar. 2019

Accepted: 2 Dec. 2019

\title{
OUTSOURCING AS A CHALLENGE FOR ACHIEVING COMPETITIVE ADVANTAGE IN ROAD FREIGHT INDUSTRY - THE CASE OF CROATIA
}

\begin{abstract}
The purpose of this study was to explore outsourcing as a possible source of competitive advantage for road freight operators, with the empirical research directed towards the road freight transportation sector. Methodologically, this study drew on the data collected from a sample of Croatian road freight transporters. Because a certain number of transportation companies tend to outsource their resources, the insight into outsourcing activities was gained through analysing (1) the number of hired vehicles in the fleet (outsourced vehicles), and (2) the number of hired drivers (outsourced drivers). A variance inflation test, correlation and multiple regression analysis were conducted to test the model assumptions. The research results confirmed the connection between the externalised resources and the differentiation of services and staff. The main contribution and managerial implications included that the companies with a more significant number of hired vehicles in their fleet should differentiate their services. In contrast, the companies that own the majority of their vehicles should build their competitive advantage through staff differentiation.
\end{abstract}

\section{KEY WORDS}

road freight transportation; road freight industry; competitive advantage; outsourcing; logistics operators;

\section{INTRODUCTION}

Road transportation dominates the freight operations worldwide [1], and it is the most important segment of freight land transport, playing an important role in almost all economic activities, especially those that are crucial for infrastructural and socio-economic welfare. Road freight transportation ensures the delivery of products to consumers [2]. Entire industries rely on transport, in which raw materials or finished products are easily sent from one point to another $[3,10]$. Road industry represents an extremely important sector in the European Union (EU). Its road freight transportation industry alone employs 3.07 million people (this does not account for those working in vehicle production, insurance, services, road building, and maintenance and traffic control). These employees are divided among 571,046 enterprises that are registered for road freight transportation [4].

However, road freight transportation outsourcing is a widespread trend [5] characterised by complex business activities with higher risks. Thus, the crucial question is: Can outsourced resources be a source of competitive advantage? To answer this research question, it is necessary to further investigate the companies' sources of competitive advantage within the transportation industry.

If companies wish to achieve a competitive position on the market and operate with high profit margins, they have to develop at least one competitive advantage [6]. A company's competitive advantage can be defined via comparison with its competitors - in other words, competitive advantage belongs to those companies that are significantly better-performing than their competitors [7]. The existence of competitive advantage implies the existence of imperfect competition within market structures. To understand this, it is necessary to identify the 
available types of resources and their possibilities for competition [8]. The existing studies in the road freight industry have been, for the most part, directed toward research about:

- the role of road freight transportation in urban areas [9];

- the government role in road freight transportation development $[10,11]$;

- the influence of road freight transportation on the environment $[12,13]$ (and thus, how to mitigate the negative influence on the environment) [14-21];

- outsourcing in transportation [5, 22];

- innovations in the road freight industry [23-27]; and

- competitiveness on the freight transportation service market [24-27].

This study examined the importance of outsourcing in the Croatian road freight industry to explore the possibility of creating a competitive advantage based on resource outsourcing in the primary activity of these sectors. The topic is of great importance, considering that the Croatian road transport market was fully opened to all carriers from EU member states as of 1 July 2017 (after the expiry of the two plus two-year extension). It is essential to point out that small carriers dominate the Croatian road freight market (with the average number of employees being fewer than 5; in 2016, it was 4.03) [4]. They neglect the need for enlargement; therefore, it is essential that researchers give them recommendations by which they can build up their competitive advantage. For the purpose of this study, the primary research was conducted on a sample of Croatian companies that had road freight transportation registered as their primary activity. The study aimed to gather valuable insights into outsourcing as a possible source of competitive advantage for road freight operators.

The remainder of this paper is organised as follows. Section 2 gives an overview of the existing studies. Section 3 is focused on the conceptual model and the hypothesis development, while the research methodology is explained in Section 4. The results of the conducted primary research are presented in Section 5, together with an agenda for future research on outsourced resources on the road freight market. In this Section the particular emphasis on the implications for practice are defined. Finally, Section 6 provides the conclusions.

\section{LITERATURE REVIEW}

Ncube, Roberts and Vilakazi [28] conducted a case study of competition in the road freight sector in the Southern African Development Community (SADC) region - specifically, the fertiliser transport and trading in Zambia, Tanzania and Malawi. The authors concluded that competition, market structure and arrangements between companies in the road freight sector - as well as the relationship between road freight operators and large importers - played an important role in determining the prices and trading of commodities among the countries. The competitive outcomes in road freight in the context of fertiliser trading were driven by the inter-relationships between large transporters and the transport users, cross-border rivalries and both large and small regulatory interventions to enhance the outcomes of road transport. Based on their research results, they recommended improving road freight transportation by carefully monitoring the fertiliser prices, increasing co-operation between competition authorities in the SADC, fast-tracking of the implementation of pro-competitive regulations affecting road transportation, considering the effect of fertiliser subsidy programs on competitive outcomes and removing the recommended transport prices in Malawi.

Evangelista and Sweeney [27] examined the application of information and communication technologies (ICT) within the road freight transportation industry in Italy. Based on their findings, they concluded that mobile phones reached a high level of penetration as a communication mechanism with drivers, as almost $90.0 \%$ of the drivers confirmed that their entire fleet was equipped with mobile phones. However, $38.5 \%$ of the companies did not have a website nor did they use the Internet as a tool for more efficient business transactions, illustrating the transport companies' neglect of technology. To increase the efficiency and reliability whilst remaining competitive on the market, road freight transporters must continually innovate. ICT still represents one of the most significant areas of innovation. The authors stated that ICT applications lead to better planning and more optimal driving schedules, better tracking of goods and vehicles, faster transportation operations as the result of more effective data gathering and analysis, improved transaction documentation and a higher level of coordination and integration among different road transporters and supply chain participants. They 
also found that small road transporters still saw information and communication applications as an expensive investment.

Demir, Bektas and Laporte [29] conducted a systematic review of 58 publications, mainly focusing on green road freight transportation. An extensive analysis of factors affecting fuel consumption and routing problems with fuel consumption components was also carried out. Consequently, they have remarked that in most research it has been confirmed that vehicle speed is quite crucial and that it is very important to travel at a speed which ensures minimum fuel consumption for a certain journey. Also important is the weight of vehicles, so it is crucial, if possible, to always prefer lighter vehicles. Apart from $\mathrm{CO}_{2}$ emissions, future research should also focus on other externalities (accidents, noise, environment damages, ...) caused by traffic.

Streimikiene, Baležentic and Baležentiene [30] conducted a comparative assessment of road transport technologies. They examined energy technologies in the road transport sector regarding atmospheric emissions and costs in an attempt to determine the most competitive and environmentally friendly transport technologies. The authors pointed out the concerning increase in greenhouse gas emissions in the traffic sector when other sectors had been recording reductions.

Litschke and Knitschky [18] also analysed future development in road freight transportation regarding more environmentally friendly vehicle technologies. Monitoring the pollution caused by the transport of goods occupies an important place in most national as well as European development policies. The authors emphasised that, in order to achieve the goals for 2030 from the White Paper [31], it would be necessary to develop more efficient technologies and alternative fuels that could significantly reduce $\mathrm{CO}_{2}$ emissions.

Matos and Silva [32] investigated the rebound effect in road freight transportation in the context of Portugal. They analysed data from the road freight transportation sector in Portugal from 1987 to 2006, determining that an increase in energy efficiency did not cause a rebound effect - it did, however, cause a total direct rebound effect of $24.1 \%$. In addition, fleet operators were more inclined to adopt operational efficiency than technological fuel efficiency as a means of increasing total operational efficiency.
McKinnon and Piecyk [33] investigated the measurement of $\mathrm{CO}_{2}$ emissions from road freight transportation in the United Kingdom. The authors suggested that, over the past several years (from 2006 to 2008), many transporters whose primary activity was road transport have been expanding their businesses by providing storage services. Further, there were big differences among the national road freight industries regarding the share of transport activities outside the country borders.

Lazauskas et al. [34] investigated competitiveness among road transport companies in Lithuania. They stated that most companies paid the largest amount of attention to price, delivery time, and safety. Only those companies that transported smaller amounts of goods paid attention to marketing strategy, whereas larger companies were committed more to services and resources. In the context of international freight transportation, the consumers tended to favour those companies that owned their freight vehicles. If road freight transportation companies wish to attract more clients, they should, first and foremost, continually improve the reliability of their services and subsequently their reputation.

Marchington, Carroll and Boxall [35] investigated the lack of workforce in the road freight transportation industry and its influence on small companies - for the purpose of their research, they created a modified version of these companies' approaches to resources. Due to the fact that it has been confirmed that the drivers represent valuable and rare resources in road freight companies, to keep them in the company, the owners have to use a variety of human resource practices. This should encourage them to be loyal to the company and to be motivated. The owners should develop a combination of path-dependent and socially complex networking abilities. The usage of informal human resource strategies are a precondition for the survival of small companies on the road freight market.

As it can be seen from the overview of the existing studies, the researchers have not devoted much attention to the business strategies that road freight transporters use, nor to detecting the competitive advantages that the biggest road freight companies seem to have, which is why the following study is extremely important for the freight transportation market. 


\section{CONCEPTUAL MODEL AND HYPOTHESIS DEVELOPMENT}

\subsection{Competitiveness in the freight transportation market}

The company competitiveness on the global market is limited by its ability to respond to immediate changes in the market and to maintain its market position. The idea of competitive advantage begins with the creation and distribution of value. A company is considered competitive when its influence determines the economic changes in the market in which it operates [36]. The ability to successfully defend its competitive advantage and to respond to its competitors is of great importance [37]. Competition is a key market element - in every business sector, there is competition among the market subjects, and the road freight industry is no different. However, it is not clear whether the companies in this industry give much attention to establishing competitive advantage (i.e. improving the quality of services they provide to predicting the actions of their competitors to controlling specific business areas) [38]. The freight transportation market is competitive when all of the participants in the market have clearly defined roles and when they effectively fulfil their role. If the transportation of chemicals, specialised freight or other goods requiring special regimes is in question, competition is almost always absent [39].

Competition in the road freight transportation industry can be established according to the level of competition for potential orders and by considering a company's ability to satisfy a client's transportation needs. The competitiveness of a company specialising in freight transportation can be defined as a combination of technological changes, services, equipment, effectiveness, equipment handling, development of new technologies and innovative products, information dissemination, added-value services, integration channels and technical and scientific staff. These factors only determine the indirect and immediate influence of the technological environment, people and implementation of innovations within the company -they do not include other essential factors of competitiveness [40]. The most important factor to become competitive on the road freight market is a combination of company reputation and the compliance of set terms of delivery and other terms from the contract [41]. The road freight transportation sector is an excellent example of an industry that is distinguished by the extreme pressures of competition.

In contrast, clients always expect high level of services in combination with lower prices. In this kind of environment, the competitiveness of road freight transportation companies increasingly depends on their ability to embrace innovations [42]. One of the critical drivers of change in the road freight industry is ICT. The main advantage of using ICT is that a company can react much more quickly to the client's demands. Quick response undoubtedly lowers the costs, which is the result of optimising transportation operations [43]. Even when they achieve a competitive advantage, transportation companies must constantly adjust to the market and innovate. Otherwise, considering the vast number of competing companies, long-term sustainability is hard to achieve.

According to the resource approach, the need for outsourcing arises as a means to eliminate the company weaknesses caused by its lack of valuable, rare and organised resources and capabilities [44]. If a company is small and has limited resources, then it should implement outsourcing as much as possible [45].

\subsection{Development, purpose and goals of outsourcing}

Establishing and continually increasing competitiveness are critical tasks in every company. To ensure successful business dealings in both domestic and international markets, companies should continuously explore new ways to strengthen their competitiveness. One of the ways this can be achieved is to use outsourcing, which many sectors have recently incorporated into almost all their activities and areas [46]. If a company lacks the essential resources or capabilities, it should opt to outsource [47].

Outsourcing implies a contract of cooperation between companies, where one company commits to ensuring the other specific physical or human resources over a specified period of time [48]. Every shortage of resources can be compensated via purchasing, a strategic alliance or outsourcing [49]. The tendency of companies to interconnect arises if they cannot buy specific resources via market transactions [50]. Mayer and Salomon [51], Barthelemy [52] highlight that companies opt for outsourcing due to resource shortages. Outsourcing enables companies to acquire specific resources they did not 
possess before, that the other party can efficiently deliver [53]. Company motives for associating with another company depend on the industry, business characteristics, competitive situation and entrepreneurial background [38]. There are several reasons why companies decide to implement outsourcing; however, before making this decision, a company has to re-examine the expected effects of outsourcing as well as the risks of its implementation. Ten main reasons why companies choose to outsource are as follows: (1) lowering and controlling costs, (2) focusing on the primary activities of the company, (3) gaining access to top competencies, (4) redirecting internal resources, (5) internal unavailability of resources, (6) faster benefit extraction than via reengineering, (7) a function that is difficult to manage, (8) a function that cannot be controlled, (9) releasing capital, and (10) lowering risks [54].

A company's decision to outsource, in addition to a cost-benefit analysis, should include a detailed evaluation of its finances as well as the potential efficiency and risks of engaging with a resource or service provider [55]. The overuse of outsourcing can create difficulties in renewing the company operating capability and reducing its potential for continual progress [56].

\subsection{Outsourcing as a modern approach to business strategy}

All business strategies aim to ensure the establishment of a sustainable competitive advantage. The strategy relates to finding a favourable position in the industry and exploiting a long-term competitive advantage [56]. Global market liberalisation on all levels is imperative if companies are to achieve competitiveness; therefore, companies must develop and implement different strategies in order to become more competitive. To establish competitiveness and adjust to rising market demands, companies increasingly engage in restructuring, which includes outsourcing as a business strategy [57]. A company has to choose a strategy that will allow it to occupy a unique and sustainable position in its industry [58]. The idea of strategic partnerships among companies emerged in the early 1990s - specifically, they were connected through outsourcing. Since outsourcing alters the company boundaries, it can be considered as a business strategy [59]. The implementation of outsourcing has to be in line with a company basic strategy and has to support its plan. Outsourcing is a restructuring strategy that brings flexibility and enables a quick response to market changes and demands [46]. It represents one of the most successful activities in recent business dealings, as it facilitates the use of scientific innovations, techniques and technologies with the intention of developing a competitive product or service that will satisfy the final consumer [45].

Outsourcing as a strategic choice can enable the use of superior resources, ultimately leading to a more successful business [53]. Communication and information on the conditions of outsourcing have undergone shifts, as it is necessary to focus the discussion on the company-partner relationship [57]. The critical criteria for the decision to outsource are not always financial benefits - trust between business partners, maintaining a quality business relationship and ensuring the expected levels of mutual deliveries or services are all crucial [60]. A company has to realise all the benefits and shortcomings of such a decision when it chooses to outsource as a business strategy [57].

\subsection{Hypothesis development}

Outsourcing implies risk and responsibility allocation when performing certain functions and providing services, where another company is hired to perform these activities [61]. Outsourcing is, in fact, a process of delegating certain business activities to another party that can deliver them more easily, more cheaply and more quickly [45]. Outsourcing is one of the most productive operations in modern business since most companies are trying to use innovations in science, technique and technology to satisfy their customers [62]. A company can acquire any resource it lacks through outsourcing [49, 63, 64]. Differentiation is a prerequisite for achieving a competitive advantage, and it is sustainable if the competitors are not able to acquire or imitate resources that form the basis for achieving a competitive advantage. Differentiation will only occur if the resources are rare, valuable and vital to the company $[49,65,66]$. If competing companies control the same resources, then it is necessary to take the first step in achieving a competitive advantage (i.e. implementing a strategy that other companies in the industry do not use) [67].

Activities with less strategic resources are activities that can be outsourced [68]. Businesses with low transaction costs are outsourced [69]. Companies are placing more focus on the outsourcing of activities and resources [55]. The decision to 
outsource is connected to the managers' perceptions of the effects of the existing resources on the company efficiency [50]. The company main goal is to realise above-average profitability by using all of its resources and defending its competitive position, which is vital for the production, services provision and distribution $[44,71]$.

$H_{1}$ : The use of the outsourced resources in the primary activity of the Croatian road freight transporters reduces their ability to differentiate from one another.

The outsourcing of secondary activities can have a positive effect on the business success [55, 72]. In this case, the business success grows for three reasons [73]:

1) the company can focus more on its primary activities, which

2) increases the innovations and skills related to those activities, and

3 ) improves the service quality and lowers costs.

In contrast, if a company decides to outsource its primary activity, this can limit the business success, primarily because of the transaction costs that are involved $[69,74]$.

$\mathrm{H}_{2}$ : The rise in the level of outsourced resources in the primary activity of the Croatian road freight transporters limits their business success.

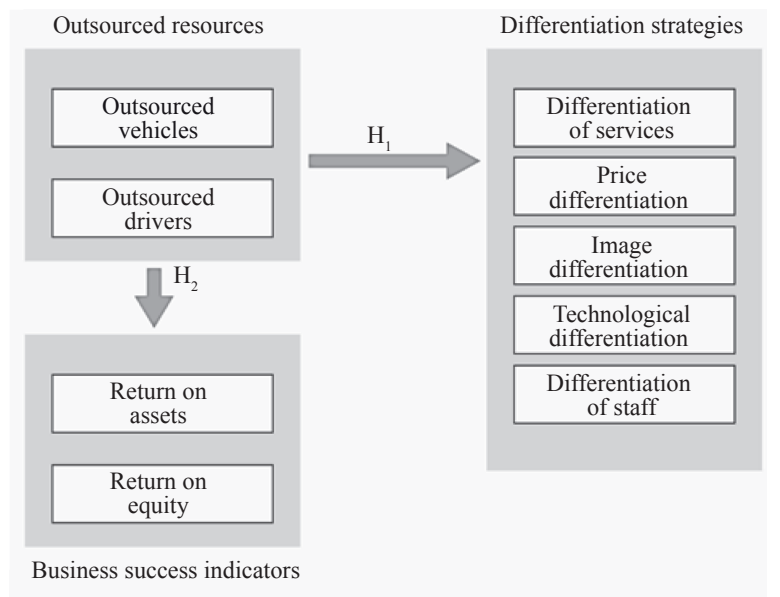

Figure 1 - Proposed conceptual model

\section{RESEARCH METHODOLOGY}

Primary research was conducted to test these hypotheses. The sample, research setting and data collection methods are explained below.

To collect useful knowledge on the business strategies of road freight transporters in Croatia, explorative research was conducted on a sample of ten companies. The research instrument was a structured interview comprised of questions that were gathered after conducting a review of the domestic and international literature via publicly accessible sources: annual reports, data published by the Croatian Bureau of Statistics and data published by the Croatian Company Directory of the Croatian Chamber of Economy. The purpose of this research was to gain insight into how outsourced resources affect the differentiation strategies and business success of road freight companies. Further, the study was conducted to define useful questions for the main research study.

A highly structured questionnaire was used as the research instrument. Pilot testing of the survey evaluated the instrument and identified and eliminated difficulties that arose while filling out the survey. The pilot study was conducted on a sample of 25 companies (companies in the Republic of Croatia that had road freight transportation registered as their primary activity with the Croatian Company Directory of the Croatian Chamber of Economy). The questionnaire was sent to the companies via e-mail. Specifically, a list of the companies who submitted financial reports for the year 2016 was considered to avoid sending the questionnaire to inactive companies. The Register of Business Entities of the Croatian Chamber of Economy was used for the sample, and 600 companies from this population were randomly selected.

The questionnaire was created in Google Docs to make filling it out easier and to ensure a higher response rate. There were both open-ended and closed questions. The respondents had to rate their level of agreement or disagreement via a seven-point Likert scale. A one indicated complete disagreement, and a seven indicated complete agreement. The questionnaire was filled out by 134 companies. Of these, 16 companies responded that road freight transportation was no longer a part of their business. Thus, the final sample size of $n=118$ (response rate: $20.2 \%$ ) was obtained.

Out of the 118 companies that filled out the questionnaire, 100 responded that they were $100 \%$ domestically owned. The average share of domestic ownership in the sample was $95.30 \%$. Regarding the distribution of the companies based on the size of the vehicle fleet, 91 companies $(71.12 \%)$ had less than 20 trucks in their fleets, and only seven companies $(5.93 \%)$ owned more than 100 trucks. 
$\mathrm{H}_{1}$ (i.e. whether using outsourced resources in the primary activity of the Croatian road freight transporters reduced their ability to differentiate from competitors) was tested using multiple regression analysis and the Pearson correlation coefficient. The independent variable was the tendency to outsource (measured by the proportion of the companies' vehicle fleets that were hired - outsourced vehicles and the proportion of their drivers that were hired - outsourced drivers). The dependent variable involved company differentiation of their services, prices, image, technological capabilities, and staff.

$\mathrm{H}_{2}$ (i.e. whether the rise in the level of the outsourced resources in the primary activity of the Croatian road freight transporters limited their business success) was tested via multiple regression analysis and the Pearson correlation coefficient. The independent variable, outsourcing in the company primary activity, was measured by the proportion of outsourced vehicles and outsourced drivers. The dependent variable was examined via non-market success indicators: profit or loss in relation to return on assets (ROA) and profit or loss in relation to return on equity (ROE). The connection between the level of outsourced resources in the primary activity and the business success of the Croatian road freight transporters was tested via an adjusted construct from previous research regarding the influence of resource outsourcing in primary business activities on the business success (Rivard et al. [75], Zhou and $\mathrm{Li} \mathrm{[76]} \mathrm{and} \mathrm{Lin}$ and $\mathrm{Wu}[77])$.

\section{RESULTS AND FUTURE RESEARCH}

The influence of using outsourced resources was measured based on the previously developed tools in relation to the differentiation of services (Langvinienè and Sližienè [40]; Evangelista and Sweeney [27]), price (Vilain and Wolfrom [78]), image (Evangelista and Sweeney [27]), technology (Zhou and Li [76]; Caerteling et al. [10]), and staff (Nieves and Haller, [79].

Before applying the regression analyses on the influence of outsourced resources on the selected strategies of differentiation, this study calculated the correlation matrix of the outsourced resources and the differentiation strategies (Table 1). The Variance inflation factor (VIF) test confirmed that there was

Table 1 - Correlation matrix of the outsourced resources and differentiation strategies

\begin{tabular}{|c|c|c|c|c|c|c|c|c|}
\hline & & 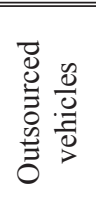 & 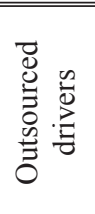 & 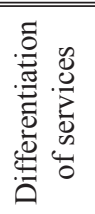 & 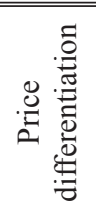 & 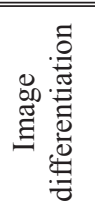 & 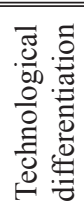 & 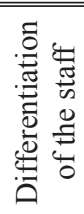 \\
\hline \multirow{3}{*}{ Outsourced vehicles } & $\bar{P}$ & - & & & & & & \\
\hline & $\mathrm{S}$ & - & & & & & & \\
\hline & $\mathrm{N}$ & - & & & & & & \\
\hline \multirow{3}{*}{ Outsourced drivers } & $\mathrm{P}$ & .180 & - & & & & & \\
\hline & $\mathrm{S}$ & .098 & - & & & & & \\
\hline & $\mathrm{N}$ & 86 & - & & & & & \\
\hline \multirow{3}{*}{ Differentiation of services } & $\mathrm{P}$ & $.327^{* *}$ & $.281^{* *}$ & - & & & & \\
\hline & $\mathrm{S}$ & .001 & .004 & - & & & & \\
\hline & $\mathrm{N}$ & 96 & 102 & - & & & & \\
\hline \multirow{3}{*}{ Price differentiation } & $\mathrm{P}$ & .118 & -.039 & .104 & - & & & \\
\hline & $\mathrm{S}$ & .252 & .697 & .267 & - & & & \\
\hline & $\mathrm{N}$ & 96 & 102 & 117 & - & & & \\
\hline \multirow{3}{*}{ Image differentiation } & $\mathrm{P}$ & .159 & .187 & $.365^{* *}$ & $.351^{* *}$ & - & & \\
\hline & $\mathrm{S}$ & .122 & .060 & .000 & .000 & - & & \\
\hline & $\mathrm{N}$ & 96 & 102 & 117 & 117 & - & & \\
\hline \multirow{3}{*}{ Technological differentiation } & $\mathrm{P}$ & .037 & -.002 & $.378^{* *}$ & $.299^{* *}$ & $.418^{* *}$ & - & \\
\hline & $\mathrm{S}$ & .721 & .987 & .000 & .001 & .000 & - & \\
\hline & $\mathrm{N}$ & 96 & 102 & 117 & 117 & 117 & - & \\
\hline \multirow{3}{*}{ Differentiation of the staff } & $\mathrm{P}$ & -.181 & -.197 & .061 & $.211^{*}$ & .084 & .052 & - \\
\hline & $\mathrm{S}$ & .082 & .051 & .525 & .026 & .382 & .591 & - \\
\hline & $\mathrm{N}$ & 93 & 99 & 111 & 111 & 111 & 111 & - \\
\hline
\end{tabular}

*** Correlation on the significance level $p<0.01 .{ }^{*}$ Correlation on the significance level $p<0.05$

$P=$ Pearson coefficient correlation; $S=$ significance; $N=$ sample size 
Naletina D, Petljak K, Rožić T. Outsourcing as a Challenge for Achieving Competitive Advantage in Road Freight Industry...

Table 2 - Results of the regression models of the influence of outsourced resources and differentiation strategies

\begin{tabular}{||l|l|l|l|c|c|c|c||}
\hline \multicolumn{1}{|c|}{$\begin{array}{c}\text { Dependent } \\
\text { variable }\end{array}$} & $\begin{array}{l}\text { Independent } \\
\text { variable 1 } \\
\left(x_{1}\right)\end{array}$ & $\begin{array}{c}\text { Independent } \\
\text { variable 2 } \\
\left(x_{2}\right)\end{array}$ & Regression equation & $\begin{array}{c}\text { Probability } \\
y\end{array}$ & $\begin{array}{c}\text { Probability } \\
x_{1}\end{array}$ & $\begin{array}{c}\text { Probability } \\
x_{2}\end{array}$ & $\mathrm{R}^{2}$ \\
\hline \hline $\begin{array}{l}\text { Differentiation } \\
\text { of services }\end{array}$ & $\begin{array}{l}\text { Outsourced } \\
\text { vehicles }\end{array}$ & $\begin{array}{l}\text { Outsourced } \\
\text { drivers }\end{array}$ & $y=2.59+0.03 x_{1}+0.02 x_{2}$ & 0.000 & 0.011 & 0.106 & 0.151 \\
\hline $\begin{array}{l}\text { Price } \\
\text { differentiation }\end{array}$ & $\begin{array}{l}\text { Outsourced } \\
\text { vehicles }\end{array}$ & $\begin{array}{l}\text { Outsourced } \\
\text { drivers }\end{array}$ & $y=9.69+0.02 x_{1}-0.01 x_{2}$ & 0.000 & 0.342 & 0.674 & 0.016 \\
\hline $\begin{array}{l}\text { Image } \\
\text { differentiation }\end{array}$ & $\begin{array}{l}\text { Outsourced } \\
\text { vehicles }\end{array}$ & $\begin{array}{l}\text { Outsourced } \\
\text { drivers }\end{array}$ & $y=4.68+0.02 x_{1}+0.02 x_{2}$ & 0.000 & 0.240 & 0.264 & 0.043 \\
\hline $\begin{array}{l}\text { Technological } \\
\text { differentiation }\end{array}$ & $\begin{array}{l}\text { Outsourced } \\
\text { vehicles }\end{array}$ & $\begin{array}{l}\text { Outsourced } \\
\text { drivers }\end{array}$ & $y=13.09+0.02 x_{1}-0.02 x_{2}$ & 0.000 & 0.364 & 0.561 & 0.012 \\
\hline $\begin{array}{l}\text { Differentiation } \\
\text { of the staff }\end{array}$ & $\begin{array}{l}\text { Outsourced } \\
\text { vehicles }\end{array}$ & $\begin{array}{l}\text { Outsourced } \\
\text { drivers }\end{array}$ & $y=35.61-0.03 x_{1}-0.04 x_{2}$ & 0.000 & 0.336 & 0.036 & 0.055 \\
\hline
\end{tabular}

no multicollinearity problem with the independent variables in the conducted regression models. As Table 1 illustrates, it was evident that the more significant correlations were only the differentiation of the services and the differentiation of staff (in terms of independent variables).

The influence of the outsourced resources on the selected strategies of differentiation was observed through five regression models (see Table 2). The dependent variable, differentiation of services, summed up the answers to the statements "Your company offers the following types of transportation from those listed' and 'Beside the transportation services, your company also offers ...' The price differentiation was the result of the price competitiveness of companies inside and outside the territory of the Republic of Croatia.

In the third regression model for $\mathrm{H}_{1}$, the dependent variable was tested via the differentiation of each company's image, measured by summing regular data updates on the company's website $(\mu=3.12)$ and its investment in advertising its services $(\mu=3.01$ ). The results (Table 1) showed that image differentiation correlated weakly with the outsourced vehicles $(0.159)$ and with the outsourced drivers (0.187).

The dependent variable in the fourth regression model for $\mathrm{H}_{1}$, technological differentiation, summed up the introduction of new technologies into the vehicle fleet $(\mu=4.66)$, the investment in the fleet $(\mu=4.54)$ and the investment in the fleet equipment $(\mu=4.60)$. The correlation matrix (Table 1) illustrated that technological differentiation had almost no correlation with the outsourced vehicles (0.037) nor with the outsourced drivers (-0.002).
In the fifth regression model for $\mathrm{H}_{1}$, the dependent variable was observed via measuring staff differentiation (the sum of the answers to six statements):

1) Your company sends employees to professional training $(\mu=4.73)$.

2) The drivers in your company possess the knowledge and skills necessary to perform the transportation process successfully $(\mu=6.02)$.

3) An appropriate level of specific expertise exists in your company $(\mu=5.87)$.

4) Your employees perform services within the agreed-upon timeline $(\mu=5.94)$.

5) Your employees react quickly to customers' demands and solve problems $(\mu=5.90)$.

6) Your employees develop new ideas and knowledge $(\mu=5.10)$.

It was evident from the multiple regression analysis results that the outsourced vehicles were not significant. The outsourced drivers bore significance for the interpretation of changes in staff differentiation.

The results of the regression models confirmed that the outsourced vehicles influenced the company differentiation of services. The outsourced drivers were significant for interpreting the changes in staff differentiation, whereas in other regression models, no significant correlation between the dependent and the independent variables was found. In line with this, $\mathrm{H}_{1}$ (the use of outsourced resources in the primary activity of the Croatian road freight transporters reduces their differentiation ability) is partially accepted.

$\mathrm{H}_{2}$ of the empirical part of the research examined the influence of resource outsourcing on business success in the Croatian road freight industry (i.e. the rise in the level of outsourced resources in the 
primary activity of the Croatian road freight transporters limits their business success). The correlation coefficient matrix of the outsourced resources and the indicators of the business success were calculated before defining the regression model (Table 3). It can be seen that both the ROA and the ROE had a higher level of correlation with the outsourced vehicles.

The regression model was defined following the correlation analysis. Here, the dependent variable, the company's business success, was measured through its ROA and ROE, similar to the research by Rivard et al. [75], Zhou and Li [76] and Lin and $\mathrm{Wu}$ [77]. The independent variable, resource outsourcing, was measured through the outsourced vehicles and the outsourced drivers. As with the previous regressions, the HAC (heteroscedasticity and autocorrelation consistent) correlation was conducted to correct heteroscedastic variance.

The values of the regression analysis indicated that both the outsourced vehicles and the outsourced drivers were significant for the interpreta-

Table 3 -Correlation matrix of the outsourced resources and the indicators of business success

\begin{tabular}{|c|c|c|c|c|c|}
\hline & $\begin{array}{c}\text { Outsourced } \\
\text { vehicles }\end{array}$ & $\begin{array}{c}\text { Outsourced } \\
\text { drivers }\end{array}$ & ROE & ROA \\
\hline \multirow{3}{*}{$\begin{array}{l}\text { Outsourced } \\
\text { vehicles }\end{array}$} & $P$ & - & & & \\
\hline & $\mathrm{S}$ & - & & & \\
\hline & $\mathrm{N}$ & - & & & \\
\hline \multirow{3}{*}{$\begin{array}{l}\text { Outsourced } \\
\text { drivers }\end{array}$} & $\mathrm{P}$ & .180 & - & & \\
\hline & $\mathrm{S}$ & .098 & - & & \\
\hline & $\mathrm{N}$ & 86 & - & & \\
\hline \multirow{3}{*}{ ROE } & $\mathrm{P}$ & $-.334^{* *}$ & $-.254^{*}$ & - & \\
\hline & $\mathrm{S}$ & .002 & .020 & - & \\
\hline & $\mathrm{N}$ & 87 & 84 & - & \\
\hline \multirow{3}{*}{ ROA } & $P$ & $-.343^{* *}$ & $-.273^{* *}$ & $.583^{* * *}$ & - \\
\hline & $\mathrm{S}$ & .001 & .010 & .000 & - \\
\hline & $\mathrm{N}$ & 89 & 88 & 92 & - \\
\hline
\end{tabular}

**Correlation on the significance level $p<0.01$

${ }^{*}$ Correlation on the significance level $p<0.05$

$P=$ Pearson coefficient correlation; $S=$ significance;

$N=$ sample size tion of changes in ROA. Because the values of their coefficients were less than 0 (i.e. $\beta_{1}=-0.195220$, $\beta_{2}=-0.129152$ ), they had a negative influence on the ROA. A regression model measuring business success via ROE was then conducted.

The values in Table 4 indicate that the outsourced vehicles and the outsourced drivers were significant for the interpretation of the changes in ROE. Since $\mathrm{R}^{2}=0.1309$, this model interpreted $13.0 \%$ of the deviation. Considering that the outsourced vehicles and the outsourced drivers were significant in both regression models, $\mathrm{H}_{2}$ is accepted.

According to Neter, Wasserman and Whitmore [80] R-square is a measure of explanatory power, not fit. R-square, even when it is small, can be significantly different from 0 , and indicating that a particular regression model has statistically significant explanatory power. In the social sciences, where it is hard to specify the complete, well-specified models, low R-square values are often expected. Figure 2 shows the empirical validation of the proposed conceptual model.

The research results indicate that companies distinguished by a high share of hired vehicle fleets should seek differentiation in their services. Foremost, this implies offering additional services: storage, cumulative transportation, valet parking, labelling, documentation completion and inclusion of specific production phases. In contrast, companies with a higher share of their own vehicle fleet should build their competitive advantage via staff differentiation.

Future research should be directed toward companies that report road freight transportation as their side activity. Particular attention should be placed on researching the leading Croatian companies in the retail, wholesale, and food sectors. This type of research would enable the comparison of vehicle fleet and driver management strategies for companies that have road freight as their side activity with the companies that specialise in freight transportation.

Table 4 - Results of the regression models of the influence of the outsourced resources on business success

\begin{tabular}{||l|l|l|c|c|c|c|c||}
\hline \multicolumn{1}{|c|}{$\begin{array}{c}\text { Dependent } \\
\text { variable }\end{array}$} & $\begin{array}{c}\text { Independent } \\
\text { variable 1 } \\
\left(x_{1}\right)\end{array}$ & $\begin{array}{c}\text { Independent } \\
\text { variable 2 } \\
\left(x_{2}\right.\end{array}$ & Regression equation & $\begin{array}{c}\text { Probability } \\
y\end{array}$ & $\begin{array}{c}\text { Probability } \\
x_{1}\end{array}$ & $\begin{array}{c}\text { Probability } \\
x_{2}\end{array}$ & $\mathrm{R}^{2}$ \\
\hline \hline $\begin{array}{l}\text { Return on } \\
\text { assets }\end{array}$ & $\begin{array}{l}\text { Outsourced } \\
\text { vehicles }\end{array}$ & $\begin{array}{l}\text { Outsourced } \\
\text { drivers }\end{array}$ & $y=21.33-0.2 x_{1}-0.13 x_{2}$ & 0.000 & 0.037 & 0.000 & 0.157 \\
\hline $\begin{array}{l}\text { Return on } \\
\text { equity }\end{array}$ & $\begin{array}{l}\text { Outsourced } \\
\text { vehicles }\end{array}$ & $\begin{array}{l}\text { Outsourced } \\
\text { drivers }\end{array}$ & $y=40.75-0.27 x_{1}-0.2 x_{2}$ & 0.000 & 0.032 & 0.002 & 0.013 \\
\hline
\end{tabular}




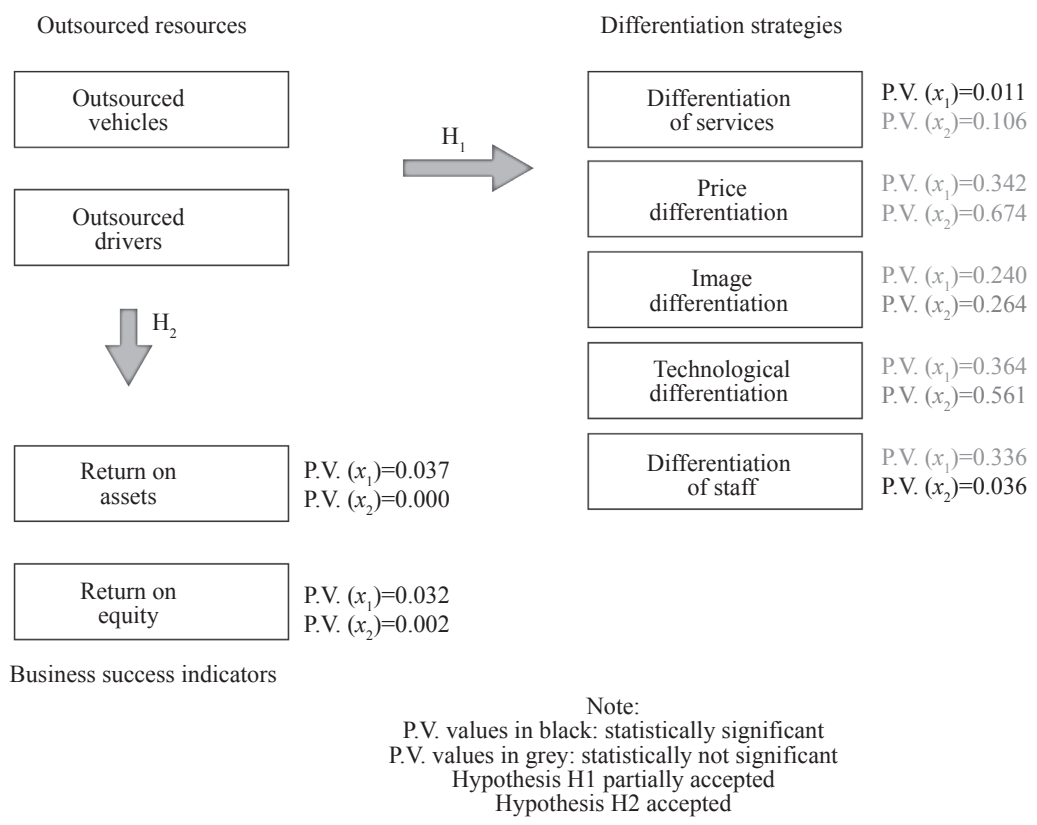

Figure 2 - Empirical validation of the proposed conceptual model

The present study examined outsourcing through shares of hired vehicle fleets and hired drivers. Future studies should investigate the influence of outsourced information systems on business success and differentiation ability in the Croatian road freight transportation industry. To test its hypotheses, this study measured business success through values of ROA and ROE in the year 2016. This is one of the present study limitations, as it considers one year; thus, it recommends that future studies should use the average values of the presented indicators for the last ten years.

\section{CONCLUSION}

Road freight transportation plays a vital role in almost all the economic activities in all of the EU member states. Requiring special examination are those activities that are crucial to infrastructural and socio-economic gain. The importance of road freight transportation for every economic system is evident in its essential role in connecting production with consumption. Considering that road freight transportation represents a significant part of road transportation, the present study focused solely on this segment.

The first part of the empirical research explored the influence of the outsourced resources in the primary activity of the Croatian road freight transporters on the limitations of their differentiation capabilities. While the second part of the empirical research analysed the influence of outsourced resources on the business success. The aim of the conducted empirical research was to provide an answer to the set research question: Can outsourced resources be a source of competitive advantage? The research results confirmed that outsourced resources can be a source of competitive advantage. It is precisely the outsourced drivers who have been confirmed as significant for interpreting changes in staff differentiation, while outsourced vehicles influenced the company differentiation of services. Study also showed that the outsourced vehicles and the outsourced drivers were significant for the interpretation of changes in ROA.

The proposed study results offer a model that enables road freight companies to build their competitive advantage based on the outsourced resources, either vehicles or drivers. By using this model, the company can estimate future plans, e.g. the need for additional vehicle fleet or investment in educated drivers to insure their business prospective, management strategy and competitive advantage.

\section{Dr. sc. DORA NALETINA ${ }^{1}$}

E-mail: dvuletic@net.efzg.hr

Dr. sc. KRISTINA PETLJAK ${ }^{1}$

E-mail: kpetljak@efzg.hr

Dr. sc. TOMISLAV ROŽIĆ2

E-mail: tomislav.rozic@fpz.hr

${ }^{1}$ Ekonomski fakultet, Sveučilište u Zagrebu

Trg J.F. Kennedy 6, 10000 Zagreb, Hrvatska

${ }^{2}$ Fakultet prometnih znanosti, Sveučilište u Zagrebu

Vukelićeva 4, 10000 Zagreb, Hrvatska 


\section{OUTSOURCING KAO IZAZOVZA POSTIZANJE KONKURENTSKE PREDNOSTI U CESTOVNOJ TERETNOJ INDUSTRIJI: PRIMJER REPUBLIKE HRVATSKE}

\section{SAŽETAK}

Svrha ovog rada je istražiti eksternalizaciju (outsourcing) kao mogući izvor konkurentske prednosti za cestovne prijevoznike tereta te je i empirijsko istraživanje bilo usmjereno prema sektoru cestovnog prijevoza. Metodološki, ovaj se rad temelji na podacima prikupljenim na uzorku hrvatskih cestovnih prijevoznika. Budući da određeni broj prijevozničkih poduzeća često eksternalizira svoje resurse, uvid u aktivnosti eksternalizacije ostvaren je analizom 1) broja unajmljenih vozila u voznom parku i 2) broja unajmljenih vozača. Za ispitivanje pretpostavki predloženog modela provedeni su test inflacije varijacije, analiza korelacije $i$ višestruka regresijska analiza. Rezultati istraživanja potvrdili su vezu između eksternaliziranih resursa i diferencijacije usluge $i$ osoblja. Najvažniji doprinos studije i smjernice za menadžment uključuju smjernice da poduzeća s više unajmljenih vozila u voznom parku trebaju diferencirati svoje usluge, dok bi, s druge strane, poduzeća koja imaju veći udio voznog parka u svojem vlasništvu, trebala graditi svoju konkurentsku prednost kroz diferencijaciju osoblja.

\section{KLJUČNE RIJEČI}

cestovni teretni prijevoz; cestovna teretna industrija; konkurentska prednost; outsourcing; logistički operateri;

\section{REFERENCES}

[1] Tob-Ogu A, Kumar N, Cullen J. ICT adoption in road freight transport in Nigeria - A case study of the petroleum downstream sector. Technological Forecasting and Social Change. 2018;131: 240-252.

[2] Engström R. The roads' role in the freight transport system. Transportation Research Procedia. 2016;14: 1443-1452.

[3] Fenelon KG. The economics of road transport. Oxon and New York: Routledge Taylor and Francis Group; 2017.

[4] European Commission. EU transport figures. Statistical pocketbook 2018. Luxembourg: Publications Office of the European Union; 2018. Available from: https:// ec.europa.eu/transport/facts-fundings/statistics/pocketbook-2018_en [Accessed $20^{\text {th }}$ October 2018].

[5] Stojanović Đ. Road freight transport outsourcing trend in Europe-what do we really know about it? Transportation Research Procedia. 2017;25: 772-793.

[6] Porter ME. Competitive Advantage. New York: The Free Press; 1985.

[7] Hamel G, Prahalad CK. Competing for the future: breakthrough strategies for seizing control of your industry and creating markets for tomorrow. Boston: Harvard Business Press Review; 1994.

[8] Grant RM. Contemporary strategy analysis. United
Kingdom: Wiley \& Sons. 2010.

[9] Arvidsson N, Woxenius J, Lammgård C. Review of road hauliers' measures for increasing transport efficiency and sustainability in urban freight distribution. Transport Reviews. 2013;33(1): 107-127.

[10] Caerteling JS, Di Benedetto A, Doree G, Halman JIM, Song M. Technology development projects in road infrastructure: The relevance of government champion behavior. Technovation. 2011;31(5-6): 270-283.

[11] Hasselgren B. Government's Role for Transport Infrastructure: Theoretical Approaches and Historical Development. PhD thesis. KTH Royal Institute of Technology; 2013.

[12] Đuranović D, Marić R, Nuševa D, Vukmirović G. Analysis of Indicators of Corporate Responsibility in Road Freight Transport: Results of Transport Companies and FMCG Retailers in Serbia. Promet - Traffic \& Transportation. 2016;28(6): 615-26.

[13] Janic M, Jovanović T. Estimating Some Social and Environmental Effects from Rail/Road Substitution in the Trans-European Transport Corridors. Promet - Traffic \& Transportation. 2012;24(4): 335-341.

[14] Han R, Yu BY, Tang BJ, Liao H, Wei YM. Carbon emissions quotas in the Chinese road transport sector: A carbon trading perspective. Energy Policy. 2017;106: 298-309.

[15] Palander T. The environmental emission efficiency of larger and heavier vehicles - A case study of road transportation in Finnish forest industry. Journal of Cleaner Production. 2017;155: 57-62.

[16] Wang Y, Sanchez Rodrigues V, Evans L. The use of ICT in road freight transport for $\mathrm{CO} 2$ reduction-an exploratory study of UK's grocery retail industry. The International Journal of Logistics Management. 2015;26(1): 2-29.

[17] Zhang Y, Thompson RG, Bao X, Jiang Y. Analyzing the promoting factors for adopting green logistics practices: A case study of road freight industry in Nanjing, China. Procedia - Social and Behavioral Sciences. 2014;125: 432-444.

[18] Litschke A, Knitschky G. Future development in road freight transport regarding more environmentally friendly vehicle technologies. Procedia - Social and Behavioral Science. 2012;48: 1557-1567.

[19] Fürst E, Oberhofer P. Greening road freight transport: evidence from an empirical project in Austria. Journal of Cleaner Production. 2012;33: 67-73.

[20] Knockaert J. Economic and technical analysis of road emissions. PhD thesis. Katholike Universiteit Leuven, Faculty of Engineering, Belgium; 2010.

[21] Piecyk MI, McKinnon AC. Forecasting the carbon footprint of road freight transport in 2020. International Journal of Production Economics. 2010;128(1): 31-42.

[22] Stojanović ĐM, Aas BØ. Transport outsourcing and transport collaboration relationship: The risk hedging perspective. Serbian Journal of Management. 2015;10(1): 33-49.

[23] Mrowczynska B, Ciesla M, Krol A, Sladkowski A. Application of Artificial Intelligence in Prediction of Road Freight Transportation. Promet - Traffic \& Transportation. 2017;29(4): 363-370.

[24] Newman P, Beatley T, Boyer H. Resilient cities: Overcoming fossil fuel dependence. Island Press; 2017. 
[25] Yu Y, Li Y, Xia T, Deng H, Bao L, Li W. Organizational mode innovation and credit supervision in road freight transportation under smart mobile devices applications services. Transportation Research Procedia. 2017;25: 762-771.

[26] Kavčić K, Suklan J, Milost F. Outsourcing Logistics Activities: Evidence from Slovenia. Promet - Traffic \& Transportation. 2016;28(6): 575-581.

[27] Evangelista P, Sweeney E. Information and communication technology adoption in the Italian road freight haulage industry. International Journal of Logistics Systems and Management. 2014;19(3): 261-282.

[28] Ncube P, Roberts S, Vilakazi T. Study of Competition in the Road Freight Sector in the SADC Region - Case Study of Fertilizer Transport and Trading in Zambia, Tanzania and Malawi. University of Johannesburg, Centre for Competition, Regulation and Economic Development (CCRED). Working Paper Series 3/2015, 2015.

[29] Demir E, Bektas T, Laporte G. A review of recent research on green road freight transportation. European Journal of Operational Research. 2014;237(3): 775-793.

[30] Streimikiene D, Baležentis T, Baležentiene L. Comparative assessment of road transport technologies. Renewable and Sustainable Energy Reviews. 2013;20: 611-618.

[31] EC-European Commission. Roadmap to a Single European Transport Area-Towards a competitive and resource efficient transport system. White Paper, Communication. 28.03.2011;144. Available from: https://eur-lex.europa.eu/legal-content/EN/TX$\mathrm{T} /$ ?qid=1488203863476\&uri=CELEX:52011DC0144 [Accessed $7^{\text {th }}$ May 2018].

[32] Matos FJ, Silva FJ. The rebound effect on road freight transport: Empirical evidence from Portugal. Energy Policy. 2011 May 1;39(5): 2833-41.

[33] McKinnon AC, Piecyk MI. Measurement of CO2 emissions from road freight transport: A review of UK experience. Energy Policy. 2009;1;37(10): 3733-3742.

[34] Lazauskas J, Bureika G, Valiūnas V, Pečeliūnas R, Matijošius J, Nagurnas S. The research on competitiveness of road transport enterprises: Lithuanian case. Transport and Telecommunication. 2012;13(2): 138-147.

[35] Marchington M, Caroll M. Labour scarcity and the survival of small firms: A resource-based view of the road haulage industry. Human Resource Management Journal. 2003;13(4): 5-22.

[36] Baublys A, Griškevičiene D, Lazauskas J, Palšaitis R. Transport economics. Vilnius: Technika; 2003.

[37] Piccoli G. Review: IT-dependent strategic initiatives and sustained competitive advantage: A review and synthesis of the literature. MIS Quarterly. 2005;29(4): 774-776.

[38] Lazauskas J, Bureika G, Valiūnas V, Pečeliūnas R, Matijošius J, Nagurnas S. The research on competitiveness of road transport enterprises: Lithuanian case. Transport and Telecommunication. 2012;13(2): 138-147.

[39] Sriraman S, Venkatesh A, Karne M, Mohite V. Competition issues in the road goods transport industry in India with special reference to the Mumbai metropolitan region. The Competition Commission of India. Final Report, 2006.

[40] Langvinienė N, Sližienė G. Factors for competitiveness in the freight transport service market: case of Lithuania.
Economics and Management. 2012;17(1): 264-271.

[41] Kowalska K. Non-market factors of competitiveness of transport, freight forwarding and logistics companies. Forum Scientiae Oeconomia. 2014;2(5): 5-17.

[42] Wagner SM. Innovation management in the German transportation industry. Journal of Business Logistics. 2008;29(2): 215-231.

[43] Schönberger J, Kopfer H. Revenue Management in roadbased freight transportation: Impacts of uncertainty of capacity consumption. International Journal of Physical Distribution \& Logistics Management. 2012;42(4): 388403.

[44] Barney JB. Resource-based theories of competitive advantage: A ten-year retrospective on the resource-based view. Journal of Management. 2001;27(6): 643-650.

[45] Tayauova G. Advantages and disadvantages of outsourcing: analysis of outsourcing practices of Kazakhstan banks. Procedia - Social and Behavioral Sciences. 2012;41: 188-195.

[46] Pavić M. Uloga outsourcinga u povećanju konkurentnosti velikih hrvatskih poduzeća na međunarodnom tržištu. Poslovna izvrsnost. 2009;3(2): 41-58. Croatian

[47] De Almeida Neves LW, Hamacher S, Scavarda LF. Outsourcing from the perspectives of TCE and RBV: A multiple case study. Production. 2014;24(3): 687-699.

[48] Sacristan NM. Consideraciones teoricas del outsourcing. Boletin economicao del ICE. 1999;1: 27-41.

[49] Grant RM. The resource-based theory of competitive advantage: implications for strategy formulation. California Management Review. 1991;33(2): 114-135.

[50] Yasuda H. Formation of strategic alliances in high-technology industries: comparative study of the resource-based theory and the transaction-cost theory. Technovation. 2005;25(7): 763-770.

[51] Mayer KJ, Salomon RM. Capabilities, Contractual Hazards, and Governance: Integrating Resource-Based and Transaction Cost Perspectives. Academy of Management. 2006;49(5): 942-959.

[52] Barthelemy J. The Hidden Costs of IT Outsourcing. MIT Sloan Management Review. 2001;42(3): 60-69.

[53] Espino-Rodriguez TF, Padron-Robaina V. A review of outsourcing from the resource-based view of the firm. International Journal of Management Reviews. 2006;8(1): 49-70.

[54] Corbett MF. The Outsourcing Revolution: Why It makes Sense and How to Do It Right. Chicago: Dearborn Trade Publishing; 2004.

[55] Tayles M, Drury C. Moving from Make/Buy to Strategic Sourcing: The Outsource Decision Process. Long Range Planning. 2001;34(5): 605-622.

[56] Bettis RA, Bradley S, Hamel G. Outsourcing and industrial decline. Academy of Management Executive. 1992;6(1): 7-22.

[57] McGrath RG. The end of competitive advantage. Boston: Harvard Business Review. 2013.

[58] Drljača M. Outsourcing kao poslovna strategija. Zbornik radova 11. međunarodnog simpozija o kvaliteti. Kvaliteta, konkurentnost i održivost, 18.-19. March 2010, Zagreb. Croatia. Hrvatsko društvo menadžera kvalitete i Oskar; 2010. p. 53-64. Croatian 
[59] Porter ME. Competitive strategy. New York: The Free Press. 1980.

[60] Insinga RC, Werle MJ. Linking outsourcing to business strategy. Academy of Management Executive. 2000;14(4): 58-70.

[61] Lacković Z. Outsourcing u održavanju. Osijek: Građevinski Fakultet; 2014. Croatian

[62] Ashley E. Outsourcing for dummies. Indianapolis: Wiley Publishing Inc; 2008.

[63] Anikin BA, Rudaya IL. Outsourcing and outstaffing. high technologies of management. Moscow: Infra-M Publishing House; 2009.

[64] Coase RH. The nature of the firm. Economica. 1937;4(16): 386-405.

[65] Díaz-Mora C. What factors determine the outsourcing intensity? A dynamic panel data approach for manufacturing industries. Applied Economics. 2008;40(19): 2509-2521.

[66] Barney JB. Firm resources and sustained competitive advantage. Journal of Management. 1991;17(1): 99-120.

[67] Peteraf MA. The cornerstones of competitive advantage: A resource based view. Strategic Management Journal. 1993;14(3): 179-191.

[68] Lieberman MB, Montgomery DB. First mover advantages. Strategic Management Journal. 1988;9(1): 41-58.

[69] Dyer J, Singh H. The relational view: Cooperative strategy and sources of interorganizational competitive advantage. Academy of Management Review. 1998;23(4): 660-679.

[70] Espino-Rodriguez TF, Padron-Robaina V. A resource-based view of outsourcing and its implications for organizational performance in the hotel sector. Tourism Management. 2005;26(5): 707-721.

[71] Barney JB. How a firm's capabilities affect boundary decisions. Sloan Management Review. 1999;40(3): 137145.

[72] Wernerfelt B. A resource-based view of the firm. Strategic Management Journal. 1984;5(2): 171-180.

[73] Lei D, Hitt M. Strategic restructuring and outsourcing: The effect of mergers and acquisitions and LBOs on building skills and capabilities. Journal of Management. 1995;21(5): 835-859.

[74] Dees GG, Rasheed A, Mclaughlin K, Priem R. The new corporate architecture. Academy of Management Executive. 1995;9(3): 7-20.

[75] Klein B, Crawford R, Alchian A. Vertical integration, appropriate rents and the competitive contracting process. Journal of Law and Economics. 1978;21: 297-326.

[76] Rivard S, Raymond L, Verreault V. Resource-based view and competitive strategy: An integrated model of the contribution of information technology to firm performance. The Journal of Strategic Information Systems. 2006;15(1): 29-50.

[77] Zhou K-Z, Li C-B. How strategic orientations influence the building of dynamic capability in emerging economies. Journal of Business Research. 2010;63(3): 224-231.

[78] Lin Y, Wu L-Y. Exploring the role of dynamic capabilities in firm performance under the resource-based view framework. Journal of Business Research. 2014;67(3): 407-413.

[79] Vilain, P, Wolfrom, P. Value Pricing and Freight Traffic: Issues and Industry Constraints in Shifting from Peak to Off-Peak Movements. Transportation Research Record. 2000;1707(1): 64-72.

[80] Nieves J, Haller S. Building dynamic capabilities through knowledge resources. Tourism Management. 2014;40: 224-232.

[81] Neter J, Wasserman W, Whitmore GA. Applied statistics. Boston: Allyn \& Bacon Press; 1988. 